\title{
VYUŽITÍ ELEKTRICKÉ ODPOROVÉ TOMOGRAFIE K VIZUALIZACI VÝPLNÍ HISTORICKÝCH STEZEK
}

\author{
Use of multielectrode resistivity survey for visualization of historical roads \\ Jan Sedláček', Martin Faměra', Ondřej Bábek', Jan Martínek² \\ ${ }^{1}$ Katedra geologie PřF UP, 17. listopadu 1192/12, 771 46 Olomouc; e-mail:jan.sedlacek@upol.cz \\ ${ }^{2}$ Centrum dopravního výzkumu, v. v. i., Wellnerova 3, 77900 Olomouc
}

(24-21 Jevíčko)

Key words: multielectrode resistivity surveying, mass specific magnetic susceptibility, geoarcheology, Moravian-Silesian Zone

\begin{abstract}
Electric resistivity tomography is suitaible method for geophysical survey of shallow subsurface subjects. We selected this method for identification of historical roads relicts. We choosed four localities for our study in the eastern part of Bohemia and north-western part of Moravia. Historical roads are detected by well defined vegetation features and the geoelectric cross sections were drawn across them. The relicts of historical roads are visible on cross resistivity sections. They manifest themselves as anomalous objects with different resistivity. The resistivity is mostly higher than surroundings due to their higher compaction. They are located in depth about $1 \mathrm{~m}$ and create oval bodies.
\end{abstract}

\section{Úvod}

Metoda elektrické odporové tomografie (electric resistivity tomography, ERT) je vzhledem k dobré dostupnosti, rychlé akvizici a poměrně jednoduchému zpracování dat efektivním nástrojem $v$ aplikovaném geologickém a archeologickém výzkumu (Milsom 2003, Tsokas et al. 2009). V souborech siliciklastických hornin se ERT osvědčila při rozlišování sedimentů písčité a štěrkové frakce, které mají vyšší měrný odpor oproti sedimentům jemnozrnnějším (Baines et al. 2002, Sass et al. 2008, Matys Grygar et al. 2013). Dále dokáže detekovat mělce pohřbená tělesa a cizorodý materiál, kontrast oproti okolnímu prostředí se zvětšuje s rostoucími rozměry a vodivostním kontrastem těchto objektů (Loeke 1999). Mezi hlavní přednosti ERT systémů patří přesné hloubkové a prostorové vymezení resistivity materiálu ve zkoumaném prostředí.

Historické stezky se $\mathrm{v}$ řadě př́padů projevují v podobě vegetačních příznaků na leteckých a satelitních snímcích, a lze je proto dobře korelovat s historickými mapami. V rámci projektu NAKI (Výzkum historických cest v oblasti severozápadní Moravy a východních Čech) bylo ERT využito $k$ detekci historických stezek. Ve většině př́padů šlo o středověké stezky. Cílem této studie bylo zjistit, jak se historické stezky, viditelné podle vegetačních příznaků, projevují ve vertikálním profilu, dále vymapovat jejich vertikální rozsah a hloubku.

\section{Území výzkumu}

Zájmovým územím (obr. 1) je oblast severozápadní Moravy a východních Čech, která je ve stř̌edoevropském měŕítku unikátem co do počtu dochovaných reliktů historických cest. Zkoumány byly lokality s nejvýraznějšími vegetač-

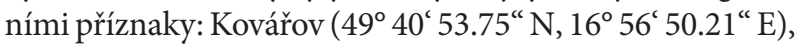
Bohuslavice ( $\left.49^{\circ} 37^{`} 22.55^{\prime \prime} \mathrm{N}, 16^{\circ} 57^{`} 59.64^{\prime \prime} \mathrm{E}\right)$, Senice na Hané $\left(49^{\circ} 36^{`} 53.08^{\prime \prime} \mathrm{N}, 17^{\circ} 3^{\mathrm{c}} 58.43^{\prime \prime} \mathrm{E}\right)$ a Slavětín (49 $\left.40^{\circ} 25.460^{\prime \prime} \mathrm{N}, 16^{\circ} 57^{`} 2.751^{\prime \prime} \mathrm{E}\right)$.

\section{Metodika}

Pro tuto studii byly na vytipovaných lokalitách zmèřeny metodou ERT $2 \mathrm{D}$ profily za použití automatického geoelektrického systému ARES (GF Instruments, s. r. o., ČR). Délka profilů se pohybovala od $31,5 \mathrm{~m}$ do $55,5 \mathrm{~m}$ v závislosti na lokálních podmínkách, zřetelnosti a šírce vegetačního příznaku. Měřicí elektrody v uspořádání Wenner - Schlumberger byly rozmístěny v linii s pravidelným krokem $0,5 \mathrm{~m}$ tak, aby bylo dosaženo co nejvyššího rozlišení.

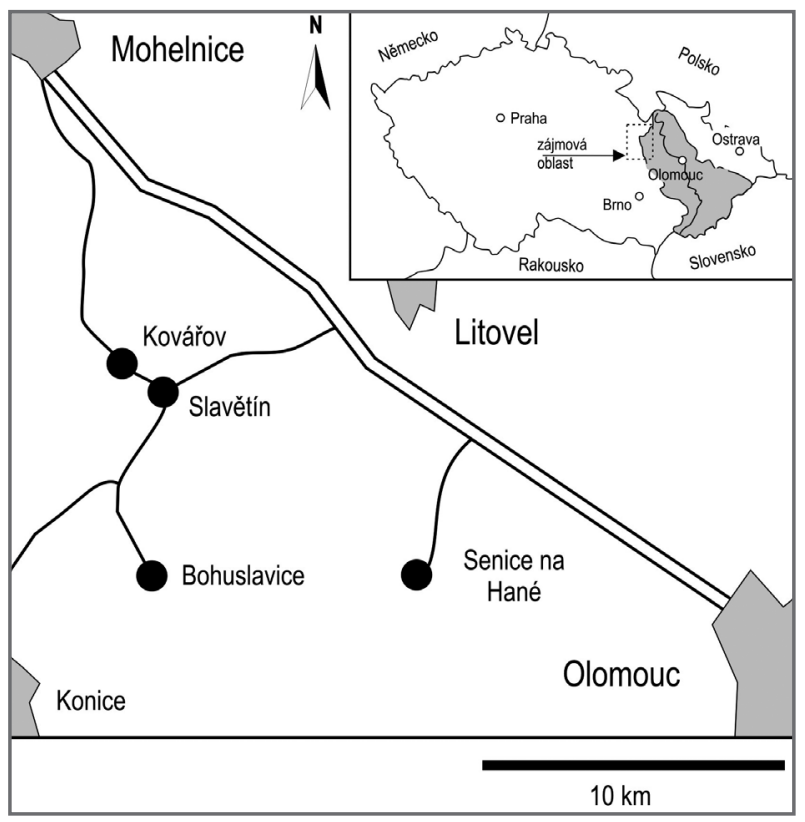

Obr. 1: Geografická pozice studovaných lokalit.

Fig. 1: Geographic setting of localities under study. 
Maximální roztažení elektrod bylo $55,5 \mathrm{~m}$, při délce impulzu 0,5 s a sčítáním dat (stacking) ze čtyř měření v každém bodě. Maximální hloubkový dosah inverzního modelu odpovídal hloubce přibližně $6 \mathrm{~m}$. Všechny profily byly vytyčeny kolmo na vegetační příznaky a byly vedeny tak, aby se střed profilu nacházel uprostřed vegetačního příznaku.

Naměřené datové body odporového pseudoprofilu byly zpracovány metodou inverze nejmenších čtverců v softwaru RES2DINV (Geotomo) a zobrazeny jako inverzní modely měrného odporu se zohledněním topografie. Rozsah hodnot maximální chyby RMS byl v rozmezí 1,7 až 2,2\%. V místech, kde byly ERT metodou nalezeny možné struktury výplně stezek, byly později vyvrtány mělké vrty (maximální hloubka vrtu $2 \mathrm{~m}$ ) pomocí přenosné vibrační vrtací soustavy (Eijkelkamp, Nizozemí) $\mathrm{s}$ jádrovnicí o průměru $4,5 \mathrm{~cm}$. Jádra byla podélně rozř́iznuta, makroskopicky popsána a navzorkována $\mathrm{v} 2 \mathrm{~cm}$ intervalech. U vysušených vzorků byla následně změřena hmotnostně specifická magnetická susceptibilita (kappa můstek KLY-4S, citlivost $3 \times 10^{-8} \mathrm{SI}$, intenzita magnetického pole $300 \mathrm{Am}^{-1}$, výrobce Agico, s. r. o. Brno).

\section{Výsledky a interpretace}

Výsledky ERT měření byly shrnuty ve formě $2 \mathrm{D}$ tomografických profilů $s$ uvedením topografie (obr. 2 a 3). Naměřené měrné odpory se pohybují v širo-

kém rozmezí hodnot od cca $\sim 20$ do $~ 300 \Omega$ m v závislosti na typu geologického podloží. Hloubka vykreslení profilů činí přibližně $6 \mathrm{~m}$. Z výsledných profilů je na základě různých měrných odporů prostředí patrné vertikální rozvrstvení do několika zón (obr. 2 a 3), které byly konfrontovány s geologickou mapou 1:50 000. Spodní vrstva na profilech je interpretována jako předkvartérní podloží tvořené karbonskými sedimenty roztáňského a protivanovského souvrství, které vykazují vyšší hodnoty měrného odporu (cca 200-300 $\Omega \cdot \mathrm{m}$ ). Kulmské horniny byly potvrzeny srovnáním s geologickou mapou a vizuálním popisem z odebraných vrtů, přičemž byly zastiženy ve velkém stupni navětrání (Lokality Bohuslavice, Kovářov a Slavětín).

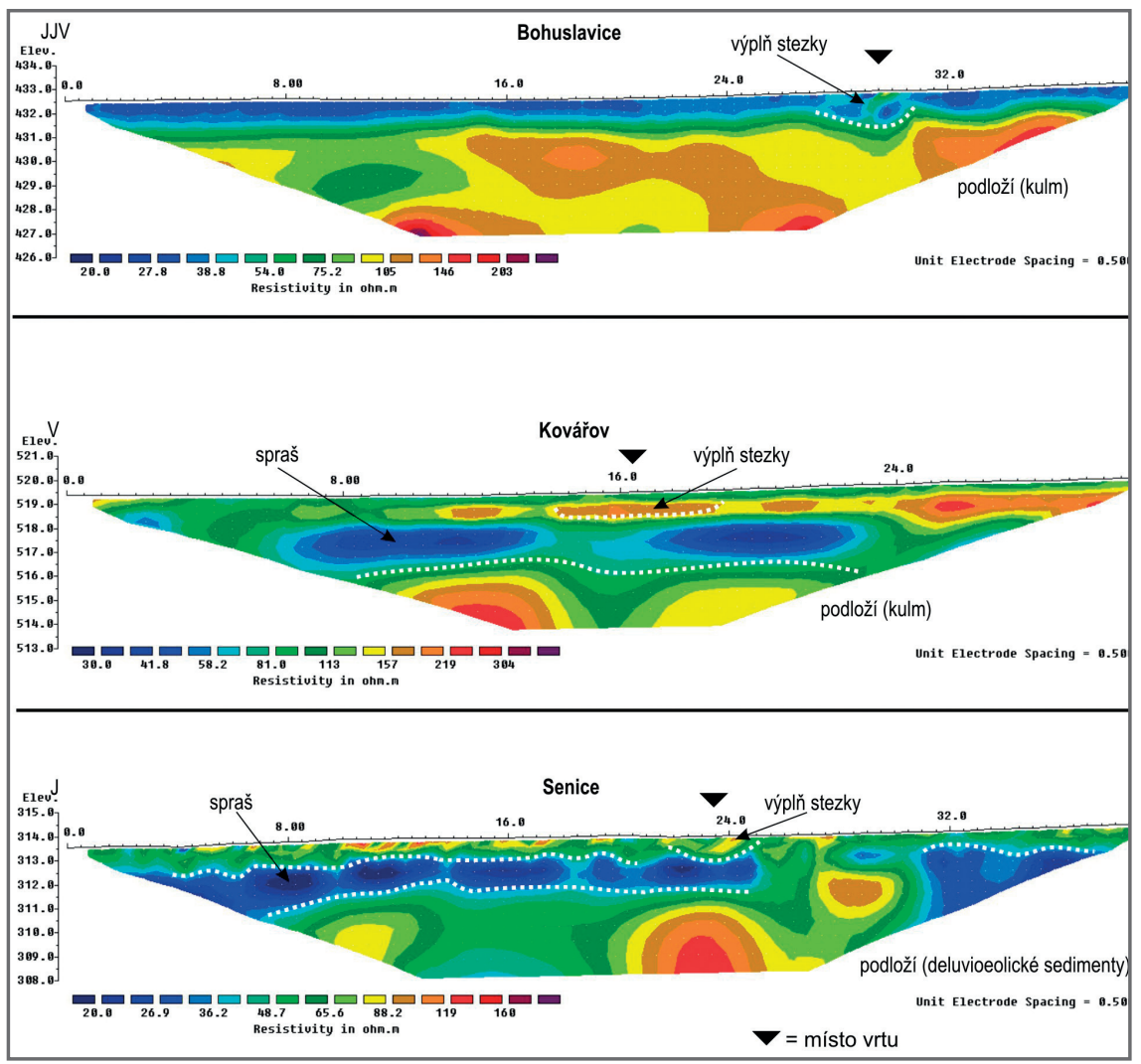

Obr. 2: ERT profily (Bohuslavice, Kovářov a Senice) s vyznačenou interpretací. Fig. 2: ERT cross sections (Bohuslavice, Kovářov a Senice) with interpretation.

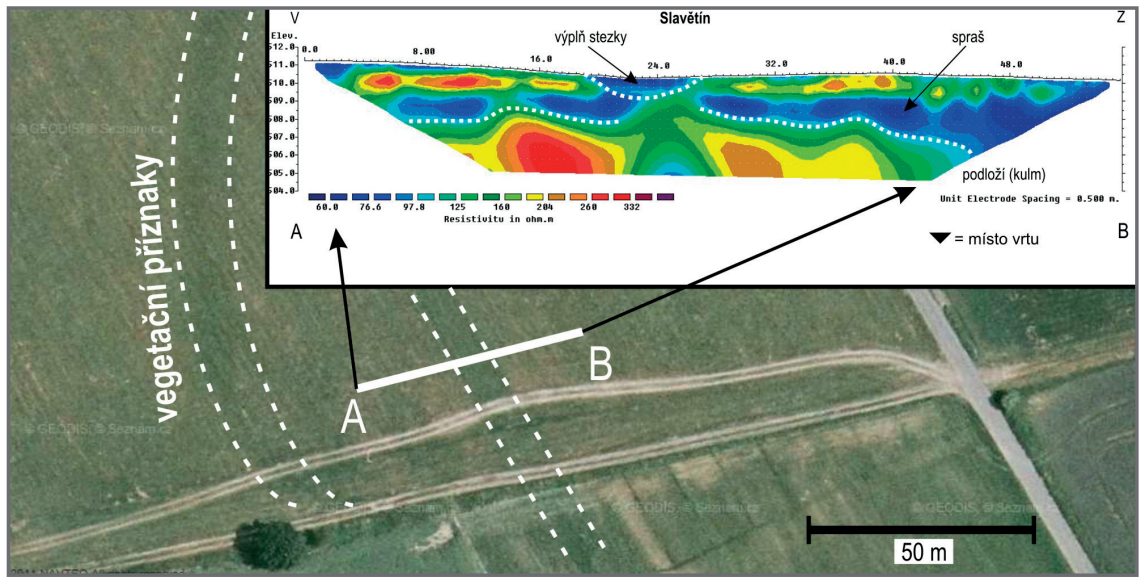

Obr. 3: ERT profil na lokalitě Slavětín s vyznačeným vegetačním příznakem.

Fig. 3: ERT cross section, Slavětín locality with vegetation features.

V Senicích je podloží tvořeno deluvioeolickými sedimenty pleistocenního stárí (měrné odpory cca 60-160 $\Omega \cdot \mathrm{m}$ ). Nadložní zóna u všech lokalit je charakterizována nízkými odpory a v profilu se jeví jako vysoce kontrastní, což je nejvíce patrné na lokalitě Senice. Tato vrstva je interpretována jako poloha spraší, jejichž typickým znakem je relativně vysoká vodivost (měrný odpor v rozsahu $\sim 30$ až $70 \Omega \cdot \mathrm{m}$ ). Povrchová zóna představuje pravděpodobně zvětralinový plášt s půdními horizonty, jejichž odlišné měrné odpory závisí také na stupni saturace vodou (Besson et al. 2004). Velmi nízké odpory lze pozorovat na lokalitě Bohuslavice (cca svrchních $60 \mathrm{~cm}$ ), naopak na lokalitě Senice jeví tato vrstva odpory vyšší. V povrchových vrstvách jsou 


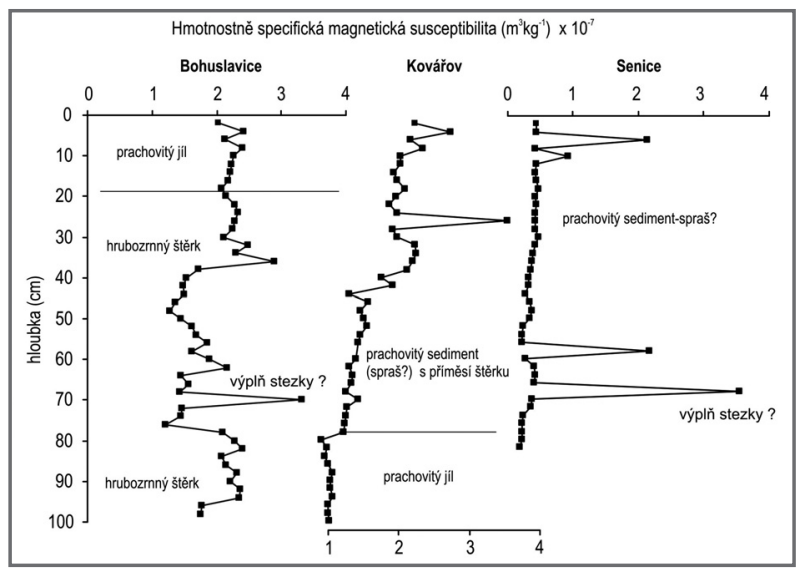

Obr. 4: Hodnoty magnetické susceptibility ve studovaných jádrech s vyznačenou interpretací.

Fig. 4: Magnetic susceptibility values with interpretation.

vyvinuty také domény čočkovitého, oválného či mísovitého tvaru, které se oproti prostředí vymezují odlišným měrným odporem a jejich báze leží většinou v hloubce cca $1 \mathrm{~m}$. Tyto anomálie svou pozicí odpovídají vegetačním příznakům historických cest a proto je lze interpretovat jako výplně historických stezek. Měrné odpory těchto těles jsou většinou vyšší, což je patrné na lokalitách Bohuslavice (50-70 $\Omega \cdot \mathrm{m})$, Kovářov (150-200 $\Omega \cdot \mathrm{m})$ a Senice (80-100 $\Omega \cdot \mathrm{m})$. V případě lokality Slavětín je možná výplň stezky charakterizována nižším měrným odporem (obr. 3). Vyšší odpor je patrně způsoben nižším stupněm kompakce oproti okolním spraším. Ke vzniku anomálií může přispívat i potenciální prrítomnost cizorodého materiálu. Lze předpokládat, že některé části stezek byly částečně zpevněny. Naopak na lokalitě Slavětín je místo vegetačního příznaku indikováno nižšími hodnotami měrného odporu a nachází se v malé prohlubni, $\mathrm{v}$ důsledku toho může těleso mít vyšší saturaci vodou.

Historické stezky byly většinou $\mathrm{v}$ minulých desetiletích $\mathrm{v}$ důsledku kolektivizace rozorány a došlo $\mathrm{k}$ přepracování půdy orbou, proto mohla být zastřena stavba v podpovrchových vrstvách.

Měření magnetické susceptibility (MS) bylo zvoleno jako podpůrná metoda pro identifikaci průběhu historických cest pod povrchem. Naměřené hodnoty MS jsou poměrně nízké (obr. 4) a pohybují se v rozmezí $1,92 \times$
$10^{-7} \mathrm{~m}^{3} \cdot \mathrm{kg}^{-1}$ až $3,55 \times 10^{-6} \mathrm{~m}^{3} \cdot \mathrm{kg}^{-1}$. Hloubkové distribuce jsou celkově bez velkých výkyvů, poměrně uniformní vývoj je patrný zejména na lokalitě Senice. $\mathrm{V}$ tomto profilu se kromě toho nacházejí tři výrazné výchylky s výrazně vyššími hodnotami (rozmezí hloubek 4-6, 56-58 a 66-68cm), což může být způsobeno přítomností cizorodého materiálu. V částech vrtu s vysokým podílem spraše dosahuje MS nejnižších hodnot. Na lokalitě Bohuslavice je nejvyšší hodnota lokalizována v hloubce $68-70 \mathrm{~cm}$, poté hodnoty opět klesají. V hloubce $36 \mathrm{~cm}$ hodnoty opět stoupají a do nadloží vykazují konstantní průběh. Vyšší MS povrchových vrstev patrně souvisí s půdním horizontem (ornice), který je dobře patrný na ERT profilu. Nárůst ve svrchních vrstvách je charakteristickým jevem (Kapička et al. 1999) a obecně souvisí s vyšší prrirozenou susceptibilitou půd (Tite - Mullins 1971). Také v profilu Kovářov lze nalézt jedno výrazné maximum (hloubka 24-26 cm), kromě této výchylky signál MS mírně do nadloží stoupá. Materiálový kontrast mezi výplní stezek a okolními horninami není patrně př́liš velký, což se projevuje na nízkém kontrastu hodnot magnetické susceptibility, především na lokalitě Kovářov.

\section{Závěr}

Na studovaných profilech byly zachyceny anomálie, které by mohly patřit výplním stezek. Od okolního prostředí se mohou lišit vyšším stupněm kompakce a jiným stupněm saturace vodou. Tato tělesa zasahují do hloubky až $1,5 \mathrm{~m}$. ERT tak představuje $\mathrm{z}$ hlediska rychlosti a přesnosti slibnou metodu pro detekci a průzkum výplní reliktů historických stezek. Výsledky měření lze podpořit a zdůraznit volbou vhodných podpůrných metod, jakými jsou např. OSL datování, hmotnostně specifická magnetická susceptibilita, kolorimetrie, stanovení obsahu TOC a $\mathrm{N}$, atd. Vyšší interpretační potenciál skrývá metoda prostorové (3D) odporové tomografie, která bude na studovaných lokalitách v budoucnu aplikována.

\section{Poděkování}

Tento výzkum byl finančně podpořen projektem DF11P01OVV029 (Výzkum historických cest v oblasti severozápadní Moravy a východních Čech) Ministerstva kultury ČR v rámci programu aplikovaného výzkumu a vývoje národní a kulturní identity (NAKI).

Literatura

Baines, D. - Smith, D. G. - Froese, D. G. - Bauman, P. - Nimeck, G. (2002): Electrical resistivity ground imaging (ERGI): a new tool for mapping the lithology and geometry of channel-belts and valley-fills. - Sedimentology, 49, 441-449.

Besson, A. - Cousin, I. - Samouëlian, A. - Boizard, H. - Richard, G. (2004): Structural heterogenity of the soil toled layer as characterized by 2D electrical surveying. - Soil and Tillage Research, 79, 239-249.

Loeke, M. H. (1999): Electrical paging surveys for environmental and engineering studies, A practical guide to 2-D and 3-D surveys. - Penang, 57 str.

Matys Grygar, T. - Nováková, T. - Bábek, O. - Elznicová, N. - Vadinová, J. (2013): Regional contamination signal of heavy metals in sediments of the Jizera River, Czech Republic: are floodplains reliable environmental archives of diffuse pollution? Science of the Total Environment, in print.

Milsom, J. (2003): Field geophysics, third edition. - Wiley, 249 pp.

Tsokas, G. N. - Tsourlos, P. I. - Papadopoulos, N. (2009): Electrical resistivity tomography: A flexible technique in solving problems of archeological research. - In: Campana, S. - Piro, S. (Eds): Seeing the unseen. Geophysics and landscape archeology, 83-126, Taylor \& Francis.

Sass, O. - Bell, R. - Glade, T. (2008): Comparison of GPR, 2D-resistivity and traditional techniques for the subsurface exploration of the Öschingen landslide, Swabian Alb (Germany). - Geomorphology, 93, 89-103. 